\title{
The plant strengthening root endophyte Piriformospora indica: potential application and the biology behind
}

\author{
P. Franken
}

Received: 15 August 2012 /Revised: 8 October 2012 /Accepted: 12 October 2012 /Published online: 31 October 2012

(C) The Author(s) 2012. This article is published with open access at Springerlink.com

\begin{abstract}
The successful conversion of plant production systems from conventional resource-exhausting to sustainable strategies depends on knowledge-based management of environmental factors. Root-inhabiting fungi came more and more into focus because their hyphae connect in ideal manner resources and challenges of the surrounding with the plant. A paradigm for such root endophytes is presented by the basidiomycete Piriformospora indica. This fungus possesses a broad host spectrum and positively affects different aspects of plant performance. This so far unique combination of attributes makes $P$. indica and its close relatives among the Sebacinales very interesting tools for cultivation of various crops. This review will outline the different aspects required to apply this root endophyte in agri- and horticulture concerning plant growth, plant nutrition and plant defence or tolerance thereby explaining what is known about the biological basis for the observed effects. Open questions and challenges for successful inoculum production and application will be discussed.
\end{abstract}

Keywords Abiotic stress tolerance $\cdot$ Induced resistance . Inoculum formulation $\cdot$ Piriformospora indica $\cdot$ Plant growth promotion $\cdot$ Sebacinales

\section{Introduction}

The rhizosphere of natural and anthropogenic ecosystems is inhabited by a plethora of organisms in which fungi

P. Franken $(\square)$

Leibniz Institute of Vegetable and Ornamental Crops,

Theodor-Echtermeyer-Weg 1,

14979 Großbeeren, Germany

e-mail: franken@igzev.de

P. Franken

Humboldt University, Institute for Biology,

Berlin, Germany constitute a large part of the biomass. Many of these rhizosphere fungi are able to colonise the plant and form different types of mycorrhiza (Smith and Read 2008). In addition, it has become evident that all plants also harbour nonmycorrhizal root-endophytic fungi, and their colonisation often impacts plant growth and development (bioregulation), plant nutrition (biofertilisation) and plant tolerance and resistance to abiotic and biotic stresses (bioprotection). Therefore, root-endophytic fungi have to be taken into account in order to understand the interaction of the root with its environment, and moreover, they could be used as biological agents to improve plant production systems.

Root endophytes with application potential can be found among non-pathogenic isolates of pathogens (Paparu et al. 2006) and among mycoparasites (Chacon et al. 2007). A morphologically defined group, the dark septate endophytes, which have been isolated from numerous plants (Jumpponen and Trappe 1998), including crops (Andrade-Linares et al. 2011), are represented by different species among the Ascomycota. A phylogenetically defined group are the Sebacinales (Basidiomycota). They contain mycorrhiza-forming and nonmycorrhizal root colonisers and occur worldwide (Weiß et al. 2011). The best-studied member is the species Piriformospora indica. It was originally isolated from the spore of an arbuscular mycorrhizal fungus found in the Thar Desert in India and root-colonising abilities were shown (Verma et al. 1998; isolate DSM 11827 deposited at the Deutsche Sammlung für Mikroorganismen und Zellkulturen, Braunschweig, Germany). In addition of forming orchid mycorrhiza (Blechert et al. 1998), plant growth-promoting effects were revealed for various hosts, and its application to plant production was proposed (Varma et al. 1999). Such a potential was further substantiated by the finding that barley plants colonised by $P$. indica were more resistant to pathogens and more tolerant to salt stress and showed higher yield (Waller et al. 2005). 
Basic research to investigate the mechanisms of the interaction between $P$. indica and plants was facilitated by the fact that the fungus interacts with Arabidopsis thaliana (Peskan-Berghofer et al. 2004). Using this model, a number of genes were identified as being involved in the interaction (for review: Oelmuller et al. 2009). Recent establishment of a transformation system and the full genome sequence of the fungus (Zuccaro et al. 2009, 2011) will likely stimulate great progress towards further functional analysis. The positive effects observed for all tested plant species implicated a biotrophic interaction between the fungus and its host. However, staining of roots with fluorescein diacetate revealed an increase in dead root cells after colonisation (Franken et al. 2000). This phenomenon is not due to necrotrophic features of the endophyte (Schäfer et al. 2009), but rather it is due to increased programmed cell death (Deshmukh et al. 2006) triggered by endoplasmatic reticulum stress and caspase 1-like activity (Qiang et al. 2012a). The current view is that the interaction starts with a short biotrophic phase followed by further saprophytic feeding on dead plant cells (Zuccaro et al. 2011). During the different stages of root colonisation, plant innate immunity is downregulated by manipulating several different phytohormone signalling pathways in order to facilitate a compatible interaction between the endophyte and the plant (Schäfer et al. 2009; Jacobs et al. 2011).

Recently, several reviews have focused on the interaction of $P$. indica with plants (Schafer et al. 2007; Oelmuller et al. 2009; Qiang et al. 2012b; Lahrmann and Zuccaro 2012). While these reviews mention potential applications, they are more concentrated on the mechanisms of interaction between the root endophyte and some model plants. Here we review significant publications related to the presence or absence of fungal effects on plant growth, plant nutrition, defence and tolerance, as well as on yield and plant product quality. The mechanisms and processes behind these effects have been investigated and described. Finally, progress and bottlenecks for inoculum production will be delineated in order to discuss future experiments which should smooth the way towards the application of $P$. indica.

\section{Plant growth and development}

The most obvious effect of $P$. indica on plants is the promotion of vegetative growth, and this has been repeatedly shown with species from various plant families (Table 1). The extent of growth promotion is typically around $50 \%$, but significant variation exists, likely due in part to a number of environmental and experimental conditions. Thus far, analysis has only been carried out on the influence of substrate and the timing of inoculation on growth promotion
(Fakhro et al. 2010). Following the course of growth parameters indicated that $P$. indica promoted initial stages of plant development (Barazani et al. 2005; Rai and Varma 2005). Further on, promotion of initial stages of vegetative growth results in an earlier switch to generative stages (Barazani et al. 2005; Achatz et al. 2010; Andrade-Linares et al. 2012). Promotion of early growth stages seems to be mainly based on accelerated root development (Waller et al. 2005; Baltruschat et al. 2008), and age-dependent regulation of genes was shifted to earlier time points in $P$. indica-colonised roots (Waller et al. 2008). Promotion of root development is an interesting feature as such. Indeed, application of $P$. indica results in enhanced rooting of callus cultures (Varma et al. 1999) and cuttings in the production of medicinal and ornamental plants (Rai and Varma 2005; Drüge et al. 2007).

Interestingly, root growth promotion can be achieved even in the absence of colonisation (Drüge et al. 2007). Therefore, it was not surprising to find $P$. indica producing the auxin indole-acetic acid (Sirrenberg et al. 2007). Although expression of auxin-regulated genes in Arabidopsis was not affected by the endophyte (Vadassery et al. 2008), such genes were induced in barley (Schäfer et al. 2009) and in Chinese cabbage (Lee et al. 2011), and their induction was causative for the strong growth-promoting effect. The inducer was, however, not the indole-acetic acid itself, but an unknown component in the exudates of the fungal hyphae (Lee et al. 2011). Ethylene typically inhibits plant growth, and some rhizobacteria produce enzymes that degrade ethylene (Hayat et al. 2010). In fact, $P$. indica seems to inhibit ethylene signalling, which could contribute to plant growth promotion (Barazani et al. 2007). The finding that although barley genes involved in ethylene synthesis are induced, ethylene-responsive genes repressed in $P$. indica-colonised roots further support this suggested role of the phytohormone (Schäfer et al. 2009). A more complex picture was drawn in Arabidopsis, where mutations in ethylene signal transduction components resulted in increased root colonisation and abolished growth promotion or even caused growth repression (Camehl et al. 2010). Hence, moderate interference with ethylene signalling may allow a certain degree of colonisation by releasing the inhibiting effect of the phytohormone. A total knock out, however, results in uncontrolled spread of $P$. indica and pathogenic behaviour. Additional phytohormones synthesised or manipulated by the root endophyte include cytokinins (Vadassery et al. 2008), gibberellins, abscisic acid and brassinosteroids (Schäfer et al. 2009). In response to colonisation, the abscisic acid pathway was proposed to enhance plant growth via calcium (Vadassery et al. 2009a), phosphoinositide and particular protein kinases (Camehl et al. 2011). In summary, nearly the whole orchestra of phytohormones and phytohormone signalling networks seems to be involved in 
Table 1 Plant growth promotion by Piriformospora indica measured as increases in fresh weight (fw) or dry weight (dw). Date of harvest is given in days after inoculation (dai)

\begin{tabular}{|c|c|c|c|c|c|}
\hline & Plant material & Inoculation & Cultivation (conditions) & $\begin{array}{l}\text { Biomass ratios } \\
\text { inoculated/control }\end{array}$ & Reference \\
\hline $\begin{array}{l}\text { Various species } \\
\text { (e.g. maize, } \\
\text { poplar, parsley) }\end{array}$ & $\begin{array}{l}\text { Seedlings or } \\
\text { plantlets }\end{array}$ & $\begin{array}{l}\text { Mycelium and spores } \\
\text { mixed with expanded } \\
\text { clay }\end{array}$ & $\begin{array}{l}\text { 4-week pot cultures in } \\
\text { greenhouses }\left(25^{\circ} \mathrm{C} \text {; }\right. \\
16 \mathrm{~h} \text { light })\end{array}$ & $\begin{array}{l}1.8-2.8(\text { shoot fw }) \\
1.5-3.5(\text { root fw })\end{array}$ & $\begin{array}{l}\text { Varma et al. } \\
\text { (1999) }\end{array}$ \\
\hline $\begin{array}{l}\text { Spilanthes calva } \\
\text { Withania somnifera }\end{array}$ & Seeds & $\begin{array}{l}\text { Seed coating }+ \text { mix } \\
\text { with field soil }\end{array}$ & $\begin{array}{l}13 \text { weeks field-grown } \\
\text { (Central India) }\end{array}$ & $\begin{array}{l}2.3 \text { or } 7.8(\text { shoot dw }) \\
1.4 \text { or } 3.3(\text { root } \mathrm{dw})\end{array}$ & Rai et al. (2001) \\
\hline $\begin{array}{l}\text { Arabidopsis } \\
\text { thaliana }\end{array}$ & $\begin{array}{r}\text { 10-day-old } \\
\text { seedlings }\end{array}$ & Agar plug & $\begin{array}{l}\text { On } \mathrm{MM} \text { medium, } 10 \% \\
\mathrm{P} \text { and } \mathrm{N} \text {, no carbohydrates, } \\
\text { continuous illumination }\end{array}$ & $\begin{array}{l}1.4\left(\text { shoot fw, } 8 \text { dai) }{ }^{\mathrm{a}}\right. \\
1.4(\text { root fw, } 5 \text { dai })^{\mathrm{a}}\end{array}$ & $\begin{array}{l}\text { Peskan- } \\
\text { Berghofer et } \\
\text { al. (2004) }\end{array}$ \\
\hline Adhatoda vasica & Cuttings & $\begin{array}{l}\text { Mycelium and spore } \\
\text { suspension to cuttings } \\
\text { in water }\end{array}$ & $\begin{array}{l}\text { Pot cultures with soil/sand/ } \\
\text { farmyard manure }(3: 1: 1) \text {; } \\
\left(22{ }^{\circ} \mathrm{C} \text {; day light; }\right. \\
\text { Central India) }\end{array}$ & $\begin{array}{l}2 \text { (whole plants } \\
\text { after } 2 \text { months) } \\
1.2 \text { (whole plants } \\
\text { after } 6 \text { months) }\end{array}$ & $\begin{array}{l}\text { Rai and Varma } \\
\text { (2005) }\end{array}$ \\
\hline Nicotiana attenuata & Seeds & $\begin{array}{l}\text { Germination on } \\
\text { plates } \pm \text { fungus }\end{array}$ & Pot cultures & $\begin{array}{l}1.9 \text { (seed germination }^{\mathrm{a}} \\
4 \text { dai }^{\mathrm{a}} \\
1.2{\text { (stalk length } 40 \text { dai })^{\mathrm{a}}}\end{array}$ & $\begin{array}{r}\text { Barazani et } \\
\text { al. (2005) }\end{array}$ \\
\hline Nicotiana tabacum & $\begin{array}{r}\text { 14-day-old } \\
\text { seedlings }\end{array}$ & Agar plug & $\begin{array}{l}\text { On MM medium, } 10 \% \\
\mathrm{P} \text { and } \mathrm{N} \text {, no carbohydrates, } \\
\text { continuous illumination }\end{array}$ & $\begin{array}{l}1.4 \text { (seedling fw } \\
\text { and } \mathrm{dw} \text { ) }\end{array}$ & $\begin{array}{l}\text { Sherameti et } \\
\text { al. (2005) }\end{array}$ \\
\hline Hordeum vulgare & Seeds & $\begin{array}{l}\text { Mycelium and spores } \\
\text { mixed with expanded } \\
\text { clay }\end{array}$ & $\begin{array}{l}5 \text {-week pot cultures in } \\
\text { green houses } \\
\left(22 / 18{ }^{\circ} \mathrm{C} ; 16 \mathrm{~h} \text { light }\right)\end{array}$ & $1.7(\text { shoot fw })^{\mathrm{a}}$ & $\begin{array}{l}\text { Waller et al. } \\
(2005)\end{array}$ \\
\hline Triticum aestivum & Seedlings & $\begin{array}{l}\text { Mycelium and spore } \\
\text { suspension added } \\
\text { to pots }\end{array}$ & $\begin{array}{l}\text { Pot cultures in greenhouse } \\
\left(22-30^{\circ} \mathrm{C} \text { without }\right. \\
\text { additional light); field } \\
\text { (Mid Europe) }\end{array}$ & 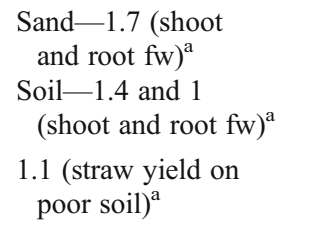 & $\begin{array}{l}\text { Serfling et al. } \\
(2007)\end{array}$ \\
\hline $\begin{array}{l}\text { Solanum } \\
\text { lycopersicum }\end{array}$ & $\begin{array}{l}\text { 4-week-old } \\
\text { plants }\end{array}$ & Root dipping & $\begin{array}{l}\text { Pot cultures in green house } \\
\left(22 / 19{ }^{\circ} \mathrm{C} \text {; no additional light }\right)\end{array}$ & $\begin{array}{l}\text { Nutrient solution-1.1 } \\
\quad \text { (shoot fw) } \\
\text { Sand-1.3 (shoot fw) } \\
\text { Commercial } \\
\text { substrate-1.1 } \\
\text { (shoot fw) }\end{array}$ & $\begin{array}{l}\text { Fakhro et al. } \\
\text { (2010) }\end{array}$ \\
\hline Chlorophytum sp. & $\begin{array}{l}\text { Micropropagated } \\
\text { plantlets }\end{array}$ & $\begin{array}{l}\text { Mycelium and spores } \\
\text { mixed with soil }\end{array}$ & $\begin{array}{l}\text { Polythene bags (greenhouse, } \\
27^{\circ} \mathrm{C} ; 13 \mathrm{~h} \text { light) } \rightarrow \text { field } \\
\text { (North India) }\end{array}$ & $\begin{array}{l}\text { Greenhouse-1.3 } \\
\quad(\text { shoot and root dw) } \\
\text { Field-1.1 (shoot dw) }\end{array}$ & $\begin{array}{l}\text { Gosal et al. } \\
\text { (2010) }\end{array}$ \\
\hline Cicer arietinum & Seeds & $\begin{array}{l}\text { Seed coating with } \\
\text { mycelium and spore } \\
\text { suspension }\end{array}$ & $\begin{array}{l}\text { Pots with soil (phytotron; } \\
22-26^{\circ} \mathrm{C} ; 16 \text { h light) }\end{array}$ & No effect & $\begin{array}{l}\text { Meena et al. } \\
\text { (2010) }\end{array}$ \\
\hline Cicer arietinum & Seeds & $\begin{array}{l}\text { Mycelium and spores } \\
\text { mixed with soil }\end{array}$ & Pots with soil (greenhouse) & 1.4 (total dry weight) & $\begin{array}{l}\text { Nautiyal et al. } \\
\text { (2010) }\end{array}$ \\
\hline Phaseolus aureus & Seeds & $\begin{array}{l}\text { Mycelium and spores } \\
\text { mixed with soil }\end{array}$ & $\begin{array}{l}\text { Greenhouse }\left(24-31^{\circ} \mathrm{C},\right. \\
11 \mathrm{~h} \text { light })\end{array}$ & $\begin{array}{l}1.4 \text { (total dw } 20 \text { dai) } \\
0.6 \text { (total dw } 60 \text { dai) }\end{array}$ & $\begin{array}{l}\text { Ray and } \\
\text { Valsalakumar } \\
\text { (2010) }\end{array}$ \\
\hline Brassica campestris & $\begin{array}{l}\text { 5-day-old } \\
\text { seedlings }\end{array}$ & Agar plug & $\begin{array}{l}15 \text { days on MM medium, } \\
1 / 2 \text { strength, } 12 \mathrm{~h} \text { light; } \\
\text { transfer to soil for } 15 \text { days }\end{array}$ & $\begin{array}{l}1.4 \text { (root fw) } \\
1.5 \text { (shoot fw) }\end{array}$ & $\begin{array}{l}\text { Sun et al. } \\
(2010)\end{array}$ \\
\hline Piper nigrum & $\begin{array}{l}\text { Tissue cultured } \\
\text { plants }\end{array}$ & $\begin{array}{l}\text { Mycelium and spores } \\
\text { mixed with sand }\end{array}$ & 60 days in pot cultures & $\begin{array}{l}\text { Effects on leave } \\
\text { number (1.2) and fw } \\
(1.1) \text {, but not on dw }\end{array}$ & $\begin{array}{l}\text { Anith et al. } \\
\text { (2011) }\end{array}$ \\
\hline Glycine $\max$ & Seeds & Soil cultures of the fungus & Not reported & $\begin{array}{l}1.1 \text { (height) with } \\
\text { cultivar JS-335 } \\
\text { no effect with } \\
\text { cultivar TAMS-21 }\end{array}$ & $\begin{array}{l}\text { Rathod et al. } \\
\text { (2011) }\end{array}$ \\
\hline
\end{tabular}


Table 1 (continued)

\begin{tabular}{|c|c|c|c|c|c|}
\hline & Plant material & Inoculation & Cultivation (conditions) & $\begin{array}{l}\text { Biomass ratios } \\
\text { inoculated/control }\end{array}$ & Reference \\
\hline Foeniculum vulgare & Seedlings & $\begin{array}{l}\text { Mycelium and spores } \\
\text { added to seedlings in } \\
\text { pots (sand/peat/perlite) }\end{array}$ & $\begin{array}{l}15 \text { days in greenhouse } \\
\left(25 / 18{ }^{\circ} \mathrm{C}, 16 \mathrm{~h} \text { light }\right)\end{array}$ & $\begin{array}{l}1.3(\operatorname{root} \mathrm{fw})^{\mathrm{a}} \\
1.2(\operatorname{shoot} \mathrm{fw})^{\mathrm{a}}\end{array}$ & $\begin{array}{l}\text { Dolatabadi } \\
\text { et al. (2011a) }\end{array}$ \\
\hline Thymus vulgaris & $\begin{array}{l}\text { Non-rooted } \\
\text { cuttings }\end{array}$ & Agar plug & $\begin{array}{l}60 \text { days on agar }\left(25^{\circ} \mathrm{C}\right) \\
30 \text { days on agar } \\
120 \text { days in substrate } \\
\text { (sand/peat/perlite; } \\
24 / 18^{\circ} \mathrm{C}, 16 \mathrm{~h} \text { light) }\end{array}$ & $\begin{array}{l}3.5(\text { root fw }) ; 3.7 \\
\quad(\text { shoot fw) } \\
2(\text { root fw }) ; 1.4(\text { shoot fw })\end{array}$ & $\begin{array}{l}\text { Dolatabadi } \\
\text { et al. (2011b) }\end{array}$ \\
\hline Vigna mungo & Seeds & Seed coating & $\begin{array}{l}\text { Greenhouse } \\
\text { Field }\end{array}$ & $\begin{array}{l}2.7(\text { shoot dw }) \\
2.5(\text { shoot dw })\end{array}$ & $\begin{array}{l}\text { Kumar et al. } \\
\text { (2012a) }\end{array}$ \\
\hline $\begin{array}{r}\text { Fragaria } \mathrm{x} \\
\text { ananassa }\end{array}$ & $\begin{array}{l}\text { Micropropagated } \\
\text { plantlets }\end{array}$ & $\begin{array}{l}\text { Mycelium and spores } \\
\text { added to seedlings in } \\
\text { pots (vermiculite/peat/ } \\
\text { solirite) }\end{array}$ & $\begin{array}{l}\text { (Phytotron; } 28^{\circ} \mathrm{C} ; \\
16 \text { h light) }\end{array}$ & 1.3 (plant fw) & $\begin{array}{l}\text { Husaini et al. } \\
\text { (2012) }\end{array}$ \\
\hline Centella asiatica & Rooted plantlets & Mycelium + spore & $\begin{array}{l}\text { Liquid MS + PDB in } \\
\text { glass bottles }\left(23^{\circ} \mathrm{C} \text {; }\right. \\
16 \mathrm{~h} \text { light })\end{array}$ & $\begin{array}{l}1.4 \text { (whole plants fw) } \\
1.75 \text { (whole plants dw) }\end{array}$ & $\begin{array}{l}\text { Satheesan et al. } \\
\text { (2012) }\end{array}$ \\
\hline
\end{tabular}

Repetitive experiments with the same plant species are not mentioned, except results were very different

${ }^{a}$ Approximate values deduced from graphs

generating compatible interactions between the fungus and host, which lead to increased early root growth promotion and finally to greater biomass.

\section{Plant nutrition}

Rhizosphere microorganisms are able to support plant nutrition by two general mechanisms. They convert unavailable resources to plant available compounds, e.g. by nitrogen fixation or phosphate solubilisation, or they support their transport towards or even inside the plant root, both leading to increased mineral nutrient uptake by the plant (Hayat et al. 2010). In tobacco, barley and green gram, colonisation did not increase $\mathrm{P}$ or $\mathrm{N}$ content of plants although plant growth was promoted (Barazani et al. 2005; Achatz et al. 2010; Ray and Valsalakumar 2010). Chickpea and black lentil plants, however, showed higher N, P and K content (Nautiyal et al. 2010; Kumar et al. 2012a), and sugar cane plants could overcome Fe and $\mathrm{Cu}$ deficiencies if inoculated with the endophyte (Gosal et al. 2011). In Arabidopsis, uptake of radio-labelled $P$ was strongly enhanced in the presence of the fungus (Shahollari et al. 2005), and such uptake was abolished in maize by downregulation of one of the fungal phosphate transporters (Yadav et al. 2010). Similarly, a nitrate reductase shows enhanced expression in $P$. indica-colonised roots which could indicate that the fungus also supports $\mathrm{N}$ nutrition of plants (Sherameti et al. 2005).

At the moment, it appears as chicken-and-egg question: does $P$. indica-enhanced root development result in increased mineral nutrient uptake, or is more direct support of plant nutrition primarily responsible for the plant growthpromoting effects of colonisation? More targeted research is necessary to know which combinations of physical and chemical soil properties allow the fungus to contribute to plant nutrition and which of the two mechanisms mentioned above are involved. Especially important will be the analysis of conditions where the application of mineral fertilisers is reduced and exchanged with different types of organic matter that could serve as a resource for the saprophytic capabilities of $P$. indica. At least and in contrast to arbuscular mycorrhizal fungi, $P$. indica colonise plant roots independent of phosphate availability (Varma et al. 1999). This is a clear advantage for agricultural applications because the fungus can be applied even in anthropogenic ecosystems with high concentrations of phosphate where it also exerts plant growth-promoting effects (Achatz et al. 2010).

The need for more research also applies to the question of whether there is a reciprocal transfer of carbohydrates, and more specifically, whether the fungus establishes an additional carbohydrate sink for the plant. The induced expression of a starch-degrading enzyme in the roots (Sherameti et al. 2005) could be a hint, but enhanced degradation of starch might be also necessary for the accelerated development of the root and so expression may merely be regulated by metabolic needs rather than induced by the fungus. Such an additional sink could lead to carbohydrate starvation, but this could be balanced by higher $\mathrm{CO}_{2}$ assimilation rates in $P$. indica-colonised barley plants at low light intensities compared to the corresponding controls (Achatz et al. 2010). 
This goes along with an analysis of chlorophyll fluorescence showing $P$. indica-increased photosynthetic performance of maize plants (Rai et al. 2008).

\section{Abiotic and biotic stresses}

The impact of biological agent application, including $P$. indica, on abiotic stress tolerance is the subject of numerous reports. Initial studies have explored how plants respond to the combination of stress factors and endophyte inoculation. If the positive impact of the endophyte is higher under stress conditions, then it can be concluded that the fungus confers stress tolerance on the plant. If the impact of the fungus is similar under stress and non-stress conditions, then it exerts its positive influence irrespective of the cultivation conditions. Decreased growth promotion by the endophyte under stress conditions implies that the plant-fungus interaction suffers in adverse conditions.

'Positive' interaction of abiotic stress and $P$. indica colonisation has been only shown for Triticum aestivum where the plant growth-promoting effect increased with rising salt concentrations (Zarea et al. 2012). In a different type of experiments, where factor interaction was not directly analysed, pre-inoculation with the endophyte relieved Arabidopsis seedlings from drought stress (Sherameti et al. 2008). Such seedlings continue to grow after water removal, but the development of non-inoculated controls is arrested. A similar phenomenon was observed in Chinese cabbage (Sun et al. 2010) and strawberry (Husaini et al. 2012). These observations cannot be simply explained by growth promotion.

In order to adapt to osmotic stress, plant tissues, e.g. of halophytes, accumulate organic solutes such as the amino acid proline (Moore 1975). Interestingly, $P$. indica-colonised plants have higher concentrations of proline than corresponding controls, and this could partially explain their increased tolerance to osmotic stress (Zarea et al. 2012). Another response to abiotic stress is the accumulation of reactive oxygen species (ROS) and the synthesis of corresponding antioxidants (Foyer and Shigeoka 2011), and it has been proposed that endophyte-conferred abiotic stress tolerance relies on an enhancement of these reactions (White and Torres 2010; Hamilton et al. 2012). Searching for the mechanisms of $P$. indica-induced stress tolerance also revealed increased conversion of dehydroascorbate to ascorbate and higher levels of glutathione, the two main antioxidants (Waller et al. 2005). Further analyses showed a significant interaction of the factors ' $P$. indica' and 'salt' on the expression of a number of enzymes involved in ROS metabolism in barley (Baltruschat et al. 2008). Such an enhanced expression was accompanied in Chinese cabbage by a clear reduction in malondialdehyde content, an indicator of unsaturated lipid degradation by ROS (Sun et al. 2010). Also the expression of a number of genes putatively involved in stress response is induced by drought to higher levels in plants colonised by $P$. indica. Interestingly, down-regulation of two genes encoding enzymes for ascorbate synthesis in Arabidopsis resulted in much greater colonisation by the endophyte and disappearance of its plant growth-promoting effect (Vadassery et al. 2009b).

Biotic stress protection by $P$. indica was first shown in barley roots against Fusarium culmorum and in shoots against Blumeria graminis (Waller et al. 2005). Since similar results have been obtained in plants from other families (Table 2), P. indica may protect a wide variety of plants against fungal pathogens. Root pathogens might be directly inhibited by antagonistic activities of the endophyte. Such growth inhibition of fungi by $P$. indica could not be observed for F. culmorum (Waller et al. 2005) or for Pseudocercosporella herpotrichoides (Serfling et al. 2007), but to a low extent for Fusarium oxysporum (Dolatabadi et al. 2012). At least for leaf pathogens, it is clear that $P$. indica root colonisation systemically induces resistance. The production of ROS and the synthesis of antioxidants seem to also play a role similar to the aforementioned abiotic stress protection, at least in the monocots barley, wheat and maize (Waller et al. 2005; Serfling et al. 2007; Kumar et al. 2009). Analysis of a number of Arabidopsis mutants showed that jasmonate signalling is important for $P$. indica-induced resistance (Stein et al. 2008). In root endophyte-colonised barley plants, a subset of defence-related genes is earlier and more strongly induced by leaf pathogens than in control plants (Molitor et al. 2011). Hence, the mechanisms of $P$. indica-induced resistance seem to be similar to the wellcharacterised induced systemic resistance described for plant growth-promoting rhizobacteria-colonised plants (van Wees et al. 2008). In contrast to fungal pathogens, colonisation of plants by the endophyte leads to a higher susceptibility to insect attack (Barazani et al. 2005) and results in increased viral spread at low light intensities in tomato (Fakhro et al. 2010).

\section{Yield and product quality}

In addition to positive effects on plant development, resistance and tolerance, $P$. indica colonisation also can improve crop plant yield, due to increased vegetative tissue yield, greater number of inflorescences and flowers (Rai et al. 2001; Dolatabadi et al. 2011a) or greater seed weight (Rai et al. 2001; Peskan-Berghofer et al. 2004; Barazani et al. 2005). For example, barley yield can be increased by $10 \%$ 
Table 2 Protection against pathogens by Piriformospora indica

\begin{tabular}{|c|c|c|c|}
\hline Plant & Pathogen & Evidence & Reference \\
\hline Hordeum vulgare & Fusarium culmorum & Effect on shoot fresh weight ${ }^{a}$ & Waller et al. (2005) \\
\hline Hordeum vulgare & Blumeria graminis & Disease symptoms & \\
\hline Hordeum vulgare & Fusarium graminearum & Pathogen spread & Deshmukh and Kogel (2007) \\
\hline Triticum aestivum & Pseudocercosporella herpotrichoides & Disease symptoms & Serfling et al. (2007) \\
\hline Triticum aestivum & Blumeria graminis & Disease symptoms & \\
\hline Arabidopsis thaliana & Golovinomyces orontii & Disease symptoms & Stein et al. (2008) \\
\hline Zea mays & Fusarium verticillioides & Effect on shoot dry weight ${ }^{a}$ & Kumar et al. (2009) \\
\hline Solanum lycopersicum & Verticillium dahliae & Disease symptoms & Fakhro et al. (2010) \\
\hline Solanum lycopersicum & Fusarium oxysporum & Effect on dry root weight ${ }^{a}$ & Sarma et al. (2011) \\
\hline Lens culinaris & Fusarium oxysporum & Disease symptoms & Dolatabadi et al. (2012) \\
\hline
\end{tabular}

${ }^{a}$ Differences between $P$. indica-inoculated plants and controls were much higher in pathogen-inoculated plants

depending on the cultivar, due to a higher number of ears (Waller et al. 2005), while in green gram, the number of pods per plant as well as the number of seeds per pod was higher (Ray and Valsalakumar 2010). In tomato, results depended on the harvest date. At early time points, twice as many fruits were harvested from colonised plants (Fakhro et al. 2010; Sarma et al. 2011), but over time non-colonised plants caught up and the same number of fruits was harvested (Andrade-Linares et al. 2012). In summary, plants with one, fixed-date of harvest seem to achieve higher yields, but in a plant like tomato with a long harvest period, the overall yield does not differ between $P$. indica-colonised plants and controls.

In addition to yield quantity, yield quality is also an important parameter. Chemical analyses showed increased concentrations of various compounds in P. indica-colonised plants such as the antifungal spilanthol in Spilanthes calva (Rai et al. 2004), pharmaceutically important substances such as podophyllotoxins from Linum album (Baldi et al. 2010), saponin from Chlorophytum sp. (Gosal et al. 2010) or asiaticoside from Centella asiatica (Satheesan et al. 2012) and essential oils in Foeniculum vulgare and Thymus vulgaris (Dolatabadi et al. 2011a, b). Moreover, as human health-promoting compounds such as antioxidants are shown to be increased in colonised plants (see above), P. indica may generally increase the quality of vegetables, fruits and seeds being used as food.

Micropropagated plantlets are another product that can benefit from the application of $P$. indica. Inoculation of such plantlets significantly increases the survival rate of tobacco, Chlorophytum species, sugar cane and strawberry (Varma et al. 1999; Sahay and Varma 1999; Mathur et al. 2008; Gosal et al. 2010, 2011; Husaini et al. 2012). This increased survival rate is probably due to both the promotion of root development and the increase in tolerance to abiotic stress.

\section{Comparison, combination and interaction with other microorganisms}

As $P$. indica belongs to the Sebacinales, a group of endophytic fungi distributed worldwide (Weiß et al. 2011), it can be assumed that close relatives show similar effects on plant performance. Closely related to $P$. indica is the orchid mycorrhiza-forming species Sebacina vermifera (Weiß et al. 2004), and indeed S. vermifera isolates (deposited at the National Institute of Agrobiological Sciences, Tsukuba, Japan; culture collection numbers are described in Deshmukh et al. 2006) show similar effects on plant growth (Barazani et al. 2005, 2007; Ghimire et al. 2009; Baldi et al. 2010; Dolatabadi et al. 2011a, b), disease resistance (Deshmukh et al. 2006; Dolatabadi et al. 2012), drought tolerance (Ghimire and Craven 2011; Husaini et al. 2012) and chemical composition (Baldi et al. 2010; Dolatabadi et al. 2011a, b). Interestingly, a related multinucleate Rhizoctonia strain was isolated from an AM fungal spore (Williams 1985), as was P. indica (Verma et al. 1998). This strain was described as a new species, Piriformospora williamsii (Sharma and Kogel 2009; Basiewicz et al. 2012), but its impact on plant performance has not yet been analysed.

$P$. indica has also been compared and combined with other beneficial microorganisms. In direct comparison with AM fungi, $P$. indica did not increase $\mathrm{P}$ and $\mathrm{N}$ content of barley plants (Achatz et al. 2010) and showed less plant growth promotion in green gram (Ray and Valsalakumar 2010), but it increased the survival of micropropagated plants to a greater extent (Mathur et al. 2008). The mycoparasite Trichoderma harzianum inhibits $P$. indica growth in vitro and root colonisation, but inoculation of pepper plants with $P$. indica and subsequently with $T$. harzianum resulted in higher plant dry weights compared to single inoculations (Anith et al. 2011). Different combinations of 
Trichoderma species with $P$. indica and $S$. vermifera were tested for their effects on protection of lentil against Fusarium wilt, and the best effects were achieved by combining the two Sebacinales with $T$. harzianum (Dolatabadi et al. 2012). $P$. indica was also compared with various plant growth-promoting rhizobacteria (fluorescent pseudomonads, Azospirillum sp.), and they showed similar effects on growth promotion, yield, salt tolerance and disease resistance (Sarma et al. 2011; Kumar et al. 2012a; Zarea et al. 2012), while P. indica was superior to the bacteria in supporting the establishment of micropropagated plantlets (Gosal et al. 2010). However, again the strongest effects resulted from combining biological agents (Meena et al. 2010; Gosal et al. 2010; Sarma et al. 2011; Kumar et al. 2012a).

\section{Inoculum production and commercial application}

In contrast to the obligate biotrophic arbuscular mycorrhizal fungi, $P$. indica can also be propagated in axenic cultures as a saprophyte and grows on numerous different natural and artificial cultivation media (Verma et al. 1998). However, the choice of substrate for inoculum production influences the impact on the plant (Andrade-Linares et al. 2012). The choice of $\mathrm{N}$ source, for example, is critical because propagation on a substrate containing only ammonium results in a strong negative effect on the plant after inoculation (Kaldorf et al. 2005).

In current experimental conditions, the fungus is typically applied as a mixture of hyphae and spores (Table 1). However, to produce inocula which can be commercially applied, it is necessary to obtain a larger quantity of spores. This can be achieved by optimisation of substrate composition and environmental conditions (Kumar et al. 2011) and by the application of certain nanomaterials (Suman et al. 2010). Additionally, for distribution, the inoculum must be combined with a carrier, and two such carriers have already been tested (Sarma et al. 2011). Other important parameters include the amount of inoculum being applied, the time point of inoculation (Fakhro et al. 2010) and the choice of soil or substrate for plant cultivation (Serfling et al. 2007; Fakhro et al. 2010).

Further, to place $P$. indica on the market, it must be registered as an inoculum. Regulations for registration vary between countries, but one bottleneck concerning safety might be that sometimes negative effects on plant growth can be observed. This is probably based on the mode of colonisation, which includes a dependency on programmed cell death (Deshmukh et al. 2006). Another concern is that the fungus was isolated in India, and at present, only this one isolate of $P$. indica exists. Because $S$. vermifera is distributed worldwide and shows similar characteristics to $P$. indica (see above), it will be useful to obtain more $S$. vermifera isolates from different regions and to analyse their impact on the plant and for their mode of colonisation. The fact that the hyphae of $P$. indica and related Sebacinales contain bacteria, which promote plant growth and disease resistance and which can at least partially be cultivated (Sharma et al. 2008), opens up the possibility of using such bacteria as inoculum. Another alternative would be the application of culture filtrate, since such filtrate can also promote plant growth and development (Varma et al. 1999; Ghimire et al. 2009; Vadassery et al. 2009a; Bagde et al. 2011; Kumar et al. 2012b) and influences the synthesis of particular valuable compounds (Balsi et al. 2010; Bagde et al. 2011; Kumar et al. 2012b).

\section{Outlook}

The interaction of $P$. indica with plant roots has been intensively studied, and genome sequence and transformation systems are available. However, in order to use the root endophyte in agricultural practice, a product for commercial use must be established and registered. For this purpose, future research concerning applications should concentrate on the following points:

- $\quad$ Evaluation of alternatives to $P$. indica, including related fungal isolates, endophytic bacteria and culture filtrate

- Inoculum production conditions

- Inoculum formulation and stability

- Persistence of the fungus in the environment

After which, it will be possible to specify scopes for application, which theoretically could be manifold as the present review has shown, and to define the conditions which support the beneficial effects. Finally, it will be necessary to calculate ecological and economic costs and benefits to guide $P$. indica and related products to successful agricultural application.

Acknowledgments The author thanks Dr. Sarah Withcomb for critical reading of the manuscript.

Open Access This article is distributed under the terms of the Creative Commons Attribution License which permits any use, distribution, and reproduction in any medium, provided the original author(s) and the source are credited.

\section{References}

Achatz B, von Ruden S, Andrade D, Neumann E, Pons-Kuhnemann J, Kogel KH, Franken P, Waller F (2010) Root colonization by Piriformospora indica enhances grain yield in barley under diverse nutrient regimes by accelerating plant development. Plant Soil 333:59-70

Andrade-Linares DR, Grosch R, Franken P, Karl HR, Kost G, Restrepo $\mathrm{S}$, de Garcia MCC, Maximova E (2011) Colonization of roots of 
cultivated Solanum lycopersicum by dark septate and other ascomycetous endophytes. Mycologia 103:710-721

Andrade-Linares DR, Müller A, Fakhro A, Schwarz D, Franken, Franken P (2012) Impact of Piriformospora indica on tomato. In: Varma A, Kost G, Oelmuller R (eds) Piriformospora indica. Springer, Berlin (in press)

Anith KN, Faseela KM, Archana PA, Prathapan KD (2011) Compatibility of Piriformospora indica and Trichoderma harzianum as dual inoculants in black pepper (Piper nigrum L.). Symbiosis 55:11-17

Bagde US, Prasad R, Varma A (2011) Influence of culture filtrate of Piriformospora indica on growth and yield of seed oil in Helianthus annus. Symbiosis 53:83-88

Baldi A, Farkya S, Jain A, Gupta N, Mehra R, Datta V, Srivastava AK, Bisaria VS (2010) Enhanced production of podophyllotoxins by co-culture of transformed Linum album cells with plant growth-promoting fungi. Pur Appl Chem 82:227241

Baltruschat H, Fodor J, Harrach BD, Niemczyk E, Barna B, Gullner G, Janeczko A, Kogel KH, Schafer P, Schwarczinger I, Zuccaro A, Skoczowski A (2008) Salt tolerance of barley induced by the root endophyte Piriformospora indica is associated with a strong increase in antioxidants. New Phytol 180:501-510

Barazani O, Benderoth M, Groten K, Kuhlemeier C, Baldwin IT (2005) Piriformospora indica and Sebacina vermifera increase growth performance at the expense of herbivore resistance in Nicotiana attenuata. Oecologia 146:234-243

Barazani O, Von Dahl CC, Baldwin IT (2007) Sebacina vermifera promotes the growth and fitness of Nicotiana attenuata by inhibiting ethylene signaling. Plant Physiol 144:1223-1232

Basiewicz M, Weiss M, Kogel KH, Langen G, Zorn H, Zuccaro A (2012) Molecular and phenotypic characterization of Sebacina vermifera strains associated with orchids, and the description of Piriformospora williamsii sp nov. Fungal Biol 116:204-213

Blechert O, Kost G, Hassel A, Rexer K-H, Varma A (1998) First remarks on the symbiotic interaction between Piriformospora indica and terrestrial orchids. In: Varma A, Hock B (eds) Mycorrhiza. Springer, Heidelberg, pp 683-688

Camehl I, Sherameti I, Venus Y, Bethke G, Varma A, Lee J, Oelmuller R (2010) Ethylene signalling and ethylene-targeted transcription factors are required to balance beneficial and nonbeneficial traits in the symbiosis between the endophytic fungus Piriformospora indica and Arabidopsis thaliana. New Phytol 185:1062-1073

Camehl I, Drzewiecki C, Vadassery J, Shahollari B, Sherameti I, Forzani C, Munnik T, Hirt H, Oelmuller R (2011) The OXI1 kinase pathway mediates Piriformospora indica-induced growth promotion in Arabidopsis. Plos Pathog 7:e1002051

Chacon MR, Rodriguez-Galan O, Benitez T, Sousa S, Rey M, Llobell A, Delgado-Jarana J (2007) Microscopic and transcriptome analyses of early colonization of tomato roots by Trichoderma harzianum. Int Microbiol 10:19-27

Deshmukh S, Hueckelhoven R, Schaefer P, Imani J, Sharma M, Weiss M, Waller F, Kogel KH (2006) The root endophytic fungus Piriformospora indica requires host cell death for proliferation during mutualistic symbiosis with barley. Proc Natl Acad Sci USA 103:18450-18457

Deshmukh SD, Kogel KH (2007) Piriformospora indica protects barley from root rot caused by Fusarium graminearum. J Plant Dis Protect 114:263-268

Dolatabadi HK, Goltapeh EM, Jaimand K, Rohani N, Varma A (2011a) Effects of Piriformospora indica and Sebacina vermifera on growth and yield of essential oil in fennel (Foeniculum vulgare) under greenhouse conditions. J Basic Microbiol 51:33-39

Dolatabadi HK, Goltapeh EM, Moieni A, Jaimand K, Sardrood BP, Varma A (2011b) Effect of Piriformospora indica and Sebacina vermifera on plant growth and essential oil yield in Thymus vulgaris in vitro and in vivo experiments. Symbiosis 53:29-35

Dolatabadi HK, Goltapeh EM, Mohammadi N, Rabiey M, Rohani N, Varma A (2012) Biocontrol potential of root endophytic fungi and Trichoderma species against Fusarium wilt of lentil under in vitro and greenhouse conditions. J Agr Sci Technol 14:407-420

Drüge U, Baltruschat H, Franken P (2007) Piriformospora indica promotes adventitious root formation in cuttings. Sci Hortic $112: 422-426$

Fakhro A, Andrade-Linares DR, von Bargen S, Bandte M, Buttner C, Grosch R, Schwarz D, Franken P (2010) Impact of Piriformospora indica on tomato growth and on interaction with fungal and viral pathogens. Mycorrhiza 20:191-200

Foyer CH, Shigeoka S (2011) Understanding oxidative stress and antioxidant functions to enhance photosynthesis. Plant Physiol 155:93-100

Franken P, Requena N, Bütehorn B, Krajinski F, Kuhn G, Lapopin L, Mann P, Rhody D, Stommel M (2000) Molecular analysis of the arbuscular mycorrhiza symbiosis. Arch Agron Soil Sci 45:271-286

Ghimire SR, Charlton ND, Craven KD (2009) The mycorrhizal fungus, Sebacina vermifera enhances seed germination and biomass production in switchgrass (Panicum virgatum L.). Bioenergy Res 2:51-58

Ghimire SR, Craven KD (2011) Enhancement of switchgrass (Panicum virgatum L.) biomass production under drought conditions by the ectomycorrhizal fungus Sebacina vermifera. Appl Environ Microbiol 77:7063-7067

Gosal SK, Karlupia A, Gosal SS, Chhibba IM, Varma A (2010) Biotization with Piriformospora indica and Pseudomonas fluorescens improves survival rate, nutrient acquisition, field performance and saponin content of micropropagated Chlorophytum sp. Indian J Biotechnol 9:289-297

Gosal SK, Sharma M, Gosal SS, Chhibba IM, Bhatnagar K, Varma A (2011) Biohardening with Piriformospora indica improves survival rate, growth, iron uptake and cane yield of micropropagated sugarcane. Inter Sugar J 113:382-388

Hamilton CE, Gundel PE, Helander M, Saikkonen K (2012) Endophytic mediation of reactive oxygen species and antioxidant activity in plants: a review. Fungal Divers 54:1-10

Hayat R, Ali S, Amara U, Khalid R, Ahmed I (2010) Soil beneficial bacteria and their role in plant growth promotion: a review. Ann Microbiol 60:579-598

Husaini AM, Abdin MZ, Khan S, Xu YW, Aquil S, Anis M (2012) Modifying strawberry for better adaptability to adverse impact of climate change. Curr Sci 102:1660-1673

Jacobs S, Zechmann B, Molitor A, Trujillo M, Petutschnig E, Likpa V, Kogel KH, Schafer P (2011) Broad-spectrum suppression of innate immunity is required for colonization of Arabidopsis roots by the fungus Piriformospora indica. Plant Physiol 156:726-740

Jumpponen A, Trappe JM (1998) Dark septate endophytes: a review of facultative biotrophic root-colonizing fungi. New Phytol 140:295-310

Kaldorf M, Koch B, Rexer KH, Kost G, Varma A (2005) Patterns of interaction between Populus Esch5 and Piriformospora indica: a transition from mutualism to antagonism. Plant Biol 7:210-218

Kumar M, Yadav V, Tuteja N, Johri AK (2009) Antioxidant enzyme activities in maize plants colonized with Piriformospora indica. Microbiology 155:780-790

Kumar V, Sahai V, Bisaria VS (2011) High-density spore production of Piriformospora indica, a plant growth-promoting endophyte, by optimization of nutritional and cultural parameters. Bioresour Technol 102:3169-3175

Kumar V, Sarma MVRK, Saharan K, Srivastava R, Kumar L, Sahai V, Bisaria VS, Sharma AK (2012a) Effect of formulated root endophytic fungus Piriformospora indica and plant growth promoting 
rhizobacteria fluorescent pseudomonads R62 and R81 on Vigna mungo. World J Microbiol Biot 28:595-603

Kumar V, Rajauria G, Sahai V, Bisaria VS (2012b) Culture filtrate of root endophytic fungus Piriformospora indica promotes the growth and lignan production of Linum album hairy root cultures. Process Biochem 47:901-907

Lahrmann U, Zuccaro A (2012) Opprimo ergo sum — evasion and suppression in the root endophytic fungus Piriformospora indica. Mol Plant Microb Interact 25:727-737

Lee YC, Johnson JM, Chien CT, Sun C, Cai DG, Lou BG, Oelmuller R, Yeh KW (2011) Growth promotion of Chinese cabbage and Arabidopsis by Piriformospora indica is not stimulated by mycelium-synthesized auxin. Mol Plant Microb Interact 24:421-431

Mathur A, Mathur AK, Verma P, Yadav S, Gupta ML, Darokar MP (2008) Biological hardening and genetic fidelity testing of microcloned progeny of Chlorophytum borivilianum Sant. et Fernand. Afr J Biotechnol 7:1046-1053

Meena KK, Mesapogu S, Kumar M, Yandigeri MS, Singh G, Saxena AK (2010) Co-inoculation of the endophytic fungus Piriformospora indica with the phosphate-solubilising bacterium Pseudomonas striata affects population dynamics and plant growth in chickpea. Biol Fertil Soil 46:169-174

Molitor A, Zajic D, Voll LM, Pons-Kuhnemann J, Samans B, Kogel KH, Waller F (2011) Barley leaf transcriptome and metabolite analysis reveals new aspects of compatibility and Piriformospora indica-mediated systemic induced resistance to powdery mildew. Mol Plant Microb Interact 24:1427-1439

Moore PD (1975) Proline implicated in halophyte osmotic adjustment. Nature 253:399-400

Nautiyal CS, Chauhan PS, DasGupta SM, Seem K, Varma A, Staddon WJ (2010) Tripartite interactions among Paenibacillus lentimorbus NRRL B-30488, Piriformospora indica DSM 11827, and Cicer arietinum L. World J Microbiol Biot 26:1393-1399

Oelmuller R, Sherameti I, Tripathi S, Varma A (2009) Piriformospora indica, a cultivable root endophyte with multiple biotechnological applications. Symbiosis 49:1-17

Paparu P, Dubois T, Gold CS, Niere B, Adipala E, Coyne D (2006) Colonisation pattern of nonpathogenic Fusarium oxysporum, a potential biological control agent, in roots and rhizomes of tissue cultured Musa plantlets. Ann Appl Biol 149:1-8

Peskan-Berghofer T, Shahollari B, Giong PH, Hehl S, Markert C, Blanke V, Kost G, Varma A, Oelmuller R (2004) Association of Piriformospora indica with Arabidopsis thaliana roots represents a novel system to study beneficial plant-microbe interactions and involves early plant protein modifications in the endoplasmic reticulum and at the plasma membrane. Physiol Plant 122:465477

Qiang X, Weiss M, Kogel KH, Schafer P (2012a) Piriformospora indica a mutualistic basidiomycete with an exceptionally large plant host range. Mol Plant Pathol 13:508-518

Qiang XY, Zechmann B, Reitz MU, Kogel KH, Schafer P (2012b) The mutualistic fungus Piriformospora indica colonizes Arabidopsis roots by inducing an endoplasmic reticulum stress-triggered caspase-dependent cell death. Plant Cell 24:794-809

Rai M, Acharya D, Singh A, Varma A (2001) Positive growth responses of the medicinal plants Spilanthes calva and Withania somnifera to inoculation by Piriformospora indica in a field trial. Mycorrhiza 11:123-128

Rai M, Varma A (2005) Arbuscular mycorrhiza-like biotechnological potential of Piriformospora indica, which promotes the growth of Adhatoda vasica Nees. Electron J Biotechnol 8:107-112

Rai MK, Varma A, Pandey AK (2004) Antifungal potential of Spilanthes calva after inoculation of Piriformospora indica. Mycoses 47:479-481

Rai MK, Shende S, Strasser RJ (2008) JIP test for fast fluorescence transients as a rapid and sensitive technique in assessing the effectiveness of arbuscular mycorrhizal fungi in Zea mays: analysis of chlorophyll a fluorescence. Plant Biosyst 142:191-198

Rathod DP, Brestic M, Shao HB (2011) Chlorophyll a fluorescence determines the drought resistance capabilities in two varieties of mycorrhized and non-mycorrhized Glycine $\max$ Linn. Afr J Microbiol Res 5:4197-4206

Ray JG, Valsalakumar N (2010) Arbuscular mycorrhizal fungi and Piriformospora indica individually and in combination with Rhizobium on green gram. J Plant Nutr 33:285-298

Sahay N, Varma A (1999) Piriformospora indica, a new biological hardening tool for micropropagated plants. FEMS Let 181:297302

Sarma MVRK, Kumar V, Saharan K, Srivastava R, Sharma AK, Prakash A, Sahai V, Bisaria VS (2011) Application of inorganic carrier-based formulations of fluorescent pseudomonads and Piriformospora indica on tomato plants and evaluation of their efficacy. J Appl Microbiol 111:456-466

Satheesan J, Narayanan AK, Sakunthala M (2012) Induction of root colonization by Piriformospora indica leads to enhanced asiaticoside production in Centella asiatica. Mycorrhiza 22:195-202

Schafer P, Khatabi B, Kogel KH (2007) Root cell death and systemic effects of Piriformospora indica: a study on mutualism. FEMS Microbiol Let 275:1-7

Schäfer P, Pfiffi S, Voll LM, Zajic D, Chandler PM, Waller F, Scholz U, Pons-Kuhnemann J, Sonnewald S, Sonnewald U, Kogel KH (2009) Manipulation of plant innate immunity and gibberellin as factor of compatibility in the mutualistic association of barley roots with Piriformospora indica. Plant J 59:461-474

Serfling A, Wirsel SGR, Lind V, Deising HB (2007) Performance of the biocontrol fungus Piriformospora indica on wheat under greenhouse and field conditions. Phytopathology 97:523-531

Shahollari B, Varma A, Oelmuller R (2005) Expression of a receptor kinase in Arabidopsis roots is stimulated by the basidiomycete Piriformospora indica and the protein accumulates in Triton X100 insoluble plasma membrane microdomains. J Plant Physiol 162:945-958

Sharma M, Schmid M, Rothballer M, Hause G, Zuccaro A, Imani J, Kampfer P, Domann E, Schafer P, Hartmann A, Kogel KH (2008) Detection and identification of bacteria intimately associated with fungi of the order Sebacinales. Cell Microbiol 10:2235-2246

Sharma M, Kogel KH (2009) Fungal isolates of the order Sebacinales provide growth promotion and systemic disease resistance to barley. IOBC WPRS Bull 43:211-215

Sherameti I, Shahollari B, Venus Y, Altschmied L, Varma A, Oelmuller R (2005) The endophytic fungus Piriformospora indica stimulates the expression of nitrate reductase and the starch-degrading enzyme glucan-water dikinase in tobacco and Arabidopsis roots through a homeodomain transcription factor that binds to a conserved motif in their promoters. J Biol Chem 280:26241-26247

Sherameti I, Tripathi S, Varma A, Oelmuller R (2008) The rootcolonizing endophyte Pirifomospora indica confers drought tolerance in Arabidopsis by stimulating the expression of drought stressrelated genes in leaves. Mol Plant Microb Interact 21:799-807

Sirrenberg A, Goebel C, Grond S, Czempinski N, Ratzinger A, Karlovsky P, Santos P, Feussner I, Pawlowski K (2007) Piriformospora indica affects plant growth by auxin production. Physiol Plant 131:581-589

Smith SE, Read DJ (2008) Mycorrhizal symbiosis. Academic, London

Stein E, Molitor A, Kogel KH, Waller F (2008) Systemic resistance in Arabidopsis conferred by the mycorrhizal fungus Piriformospora indica requires jasmonic acid signaling and the cytoplasmic function of NPR1. Plant Cell Physiol 49:1747-1751

Suman PR, Jain VK, Varma A (2010) Role of nanomaterials in symbiotic fungus growth enhancement. Curr Sci 99:1189-1191

Sun CA, Johnson J, Cai DG, Sherameti I, Oelmuller R, Lou BG (2010) Piriformospora indica confers drought tolerance in Chinese 
cabbage leaves by stimulating antioxidant enzymes, the expression of drought-related genes and the plastid-localized CAS protein. J Plant Physiol 167:1009-1017

Vadassery J, Ritter C, Venus Y, Camehl I, Varma A, Shahollari B, Novak O, Strnad M, Ludwig-Muller J, Oelmuller R (2008) The role of auxins and cytokinins in the mutualistic interaction between Arabidopsis and Piriformospora indica. Mol Plant Microb Interact 21:1371-1383

Vadassery J, Ranf S, Drzewiecki C, Mithofer A, Mazars C, Scheel D, Lee J, Oelmuller R (2009a) A cell wall extract from the endophytic fungus Piriformospora indica promotes growth of Arabidopsis seedlings and induces intracellular calcium elevation in roots. Plant J 59:193-206

Vadassery J, Tripathi S, Prasad R, Varma A, Oelmuller R (2009b) Monodehydroascorbate reductase 2 and dehydroascorbate reductase 5 are crucial for a mutualistic interaction between Piriformospora indica and Arabidopsis. J Plant Physiol 166:1263-1274

Van Wees SCM, Van der Ent S, Pieterse CMJ (2008) Plant immune responses triggered by beneficial microbes. Curr Opin Plant Biol $11: 443-448$

Varma A, Verma S, Sudah SN, Franken P (1999) Piriformospora indica, a cultivable plant growth-promoting root endophyte. Appl Environ Microbiol 65:2741-2744

Verma S, Varma A, Rexer K-H, Hassel A, Kost G, Sarbhoy A, Bisen P, Bütehorn B, Franken P (1998) Piriformospora indica, gen. nov. sp. nov., a new root-colonizing fungus. Mycologia 90:896-903

Waller F, Achatz B, Baltruschat H, Fodor J, Becker K, Fischer M, Heier T, Huckelhoven R, Neumann C, von Wettstein D, Franken P, Kogel KH (2005) The endophytic fungus Piriformospora indica reprograms barley to salt-stress tolerance, disease resistance, and higher yield. Proc Natl Acad Sci USA 102:13386-13391

Waller F, Mukherjee K, Deshmukh SD, Achatz B, Sharma M, Schaefer P, Kogel KH (2008) Systemic and local modulation of plant responses by Piriformospora indica and related Sebacinales species. J Plant Physiol 165:60-70

Weiß M, Selosse MA, Rexer KH, Urban A, Oberwinkler F (2004) Sebacinales: a hitherto overlooked cosm of heterobasidiomycetes with a broad mycorrhizal potential. Mycol Res 108:1003-1010

Weiß M, Sykorova Z, Garnica S, Riess K, Martos F, Krause C, Oberwinkler F, Bauer R, Redecker D (2011) Sebacinales everywhere: previously overlooked ubiquitous fungal endophytes. PLoS One 6:e16793

White JF, Torres MS (2010) Is plant endophyte-mediated defensive mutualism the result of oxidative stress protection? Physiol Plant 138:440-446

Williams PG (1985) Orchidaceous rhizoctonias in pot cultures of vesicular arbuscular mycorrhizal fungi. Can J Bot 63:13291333

Yadav V, Kumar M, Deep DK, Kumar H, Sharma R, Tripathi T, Tuteja N, Saxena AK, Johri AK (2010) A phosphate transporter from the root endophytic fungus Piriformospora indica plays a role in phosphate transport to the host plant. J Biol Chem 285:2653226544

Zarea MJ, Hajinia S, Karimi N, Goltapeh EM, Rejali F, Varma A (2012) Effect of Piriformospora indica and Azospirillum strains from saline or non-saline soil on mitigation of the effects of $\mathrm{NaCl}$. Soil Biol Biochem 45:139-146

Zuccaro A, Basiewicz M, Zurawska M, Biedenkopf D, Kogel KH (2009) Karyotype analysis, genome organization, and stable genetic transformation of the root colonizing fungus Piriformospora indica. Fung Genet Biol 46:543-550

Zuccaro A, Lahrmann U, Guldener U, Langen G, Pfiffi S, Biedenkopf D, Wong P, Samans B, Grimm C, Basiewicz M, Murat C, Martin F, Kogel KH (2011) Endophytic life strategies decoded by genome and transcriptome analyses of the mutualistic root symbiont Piriformospora indica. Plos Pathog 7:e1002290 